\title{
Seafood as local food: Food security and locally caught seafood on Alaska's Kenai Peninsula
}

\author{
Philip A. Loring,a,b,* S. Craig Gerlach, b and Hannah L. Harrison b \\ University of Alaska Fairbanks
}

Submitted January 25, 2013 / Revised March 29, 2013 / Accepted April 22, 2013 / Published online May 31, 2013

Citation: Loring, P. A., Gerlach, S. C., \& Harrison, H. L. (2013). Seafood as local food: Food security and locally caught

seafood on Alaska's Kenai Peninsula. Journal of Agriculture, Food Systems, and Community Development, 3(3), 13-41.

http://dx.doi.org/10.5304/jafscd.2013.033.006

Copyright (C) 2013 by New Leaf Associates, Inc.

\begin{abstract}
In this paper we explore the relationship between food security and access to locally caught seafood for communities of the Kenai Peninsula region of Alaska. Seafood and fisheries are infrequently discussed in the literature on local and small-scale food movements; instead, they are more commonly construed as overexploited components of a global food system and a source of conflict with respect to global food security and fisheries conservation. By way of contrast, we argue here that many fisheries have the potential to be sources of healthy and sustainable "local" food, in support of the many values and goals embraced by local food movement, including conservation. With data collected via a by-mail survey, we show that many
\end{abstract}

a Water and Environmental Research Center, University of Alaska Fairbanks; P.O. Box 755910; Fairbanks, Alaska 99775 USA.

b Center for Cross-Cultural Studies, University of Alaska Fairbanks; P.O. Box 756730; Fairbanks, Alaska 99775 USA.

* Corresponding author: Philip A. Loring; +1-907-474-7163; ploring@alaska.edu people in our Alaskan study region enjoy improved food security because they have access to locally caught seafood, especially those households at the lowest income levels. We also show, however, that access to these resources is still uneven for some, and we discuss strategies for improving the socialjustice aspects of this component of the regional food system. Our findings are important not just to the fisheries and food security research communities, but also for contributing to a better understanding of the conditions within which local and regional food movements can achieve the ambitious social and ecological goals they seek.

\section{Keywords}

fisheries, food security, foodways, local food, salmon, seafood, social justice, sustainability

\section{Introduction}

In this paper we report on a research project designed to explore the role of locally caught seafood in providing for food security in the Kenai Peninsula region of Alaska. Seafood and the seafood industry are well established components 
of Alaska's local economies and cultures, and many people across the state rely on local seafood that they catch themselves for a significant portion of their diet (Hanna, Frazier, Parker, \& Ikatova, 2012). Likewise, more Alaskans are employed by fisheries or fisheries-related industries than by any other sector (Northern Economics, 2011). This said, however, food insecurity is a growing problem across Alaska, especially for remote rural communities where people rely heavily on wild fish and game (Caulfield, 2002; Loring \& Gerlach, 2009). Given that Alaska's seafood industry enjoys a widespread reputation for sustainability, and as conventional wisdom features seafood so prominently in the lives and livelihoods of Alaskans, the apparent contradiction between a thriving seafood industry and food-insecure fishing-dependent communities provides an informative setting within which to explore the circumstances under which local and purportedly sustainable food resources do or do not contribute to household food security. In other words, which Alaskans enjoy reliable access to locally caught seafood, which do not, and why?

Answers to these questions are important not just to Alaskans, but to anyone who is concerned with how to achieve outcomes of individual health, social justice, and community sustainability through local and regional food movements. Many justifications are made for eating local, not the least of which include the environmental impacts of industrial, chemical-intensive agriculture (Kimbrell, 2002), the decline of rural communities and cultures (Berry, 1982), and persistent worldwide malnutrition (Shiva, 2000). However, as the de rigener alternative to the dominant system, people too easily assume a variety of positive outcomes from local food movements, including, for example, that they are more environmentally sustainable, that they produce healthier foods, and that they are more amenable to positive foodsecurity and social-justice outcomes. These assumptions are not without justification, but they are often uncritically accepted as fact; it is more accurate, perhaps, to understand food security and environmental sustainability as possible rather than inevitable outcomes of local and small-scale food systems (Born \& Purcell, 2006; Tregear, 2011;
Trivette, 2012). Thus, reflexive research on both the successes and failures of local food movements is critical if the field is to move forward.

As we discuss below, seafood and fisheries are not commonly discussed in the local and regional food movement literature, although there are a few notable exceptions (e.g., Andreatta, Nash, \& Martin, 2011; Brinson, Lee, \& Rountree, 2011; Evans-Cowley, 2011; Paolisso, 2007). Given that roughly $44 \%$ of the world's population lives on or near the coast (United Nations Environmental Programme, 2010), seafood clearly has the potential to be a major component in the rebuilding of community-based food systems. Below, we review how fisheries have been discussed in food systems and sustainability literatures, including limitations and strengths as we perceive them, and then suggest reasons for featuring seafood more prominently in local food movements. We also briefly scope the concept of food security as it is currently defined and implemented through research in Alaska and the Arctic. This regional tour of the literature is important because northern food systems have some unique characteristics when compared to other regions, such as limited local agricultural production, extremely remote communities that are not on a road system, and a very large segment of the population that relies on locally caught fish and game for a significant portion of its diet. This literature is also of interest because of the emphasis on the social and cultural dimensions of food, specifically with respect to understanding food security as more than just a biophysical or socioeconomic outcome.

Finally, we discuss our study, which took the form of community focus groups and a by-mail survey distributed to residents of the Kenai Peninsula region of Alaska. The lessons learned from the data we present are threefold, and are informative for small-scale food systems challenges globally: (1) local fisheries can play a significant role in the development of community food systems, including for low-income households; (2) individual access rights to locally available seafood resources are necessary but not sufficient to achieve food security for all stakeholders; and, (3) developing local markets that connect consumers to commercial fishers who are able to provide local 
products at a fair price is a key design and policy challenge for strengthening coastal community food systems.

\section{Seafood as Local Food}

Fisheries and seafood have not figured prominently in the academic discourse on local food, especially in the U.S., where Americans consume a growing but still not a tremendous amount of seafood in comparison to nations in Scandinavia and Asia (Food and Agriculture Organization of the United Nations [FAO], 2011). Just over 4.8 billion pounds (2.2 billion $\mathrm{kg}$ ), or roughly 16 pounds $(7.3 \mathrm{~kg}$ ) of seafood per person (edible portion) were consumed in the U.S. in 2009, the most recent year for which data are available (National Marine Fisheries Service [NMFS], 2010). Seafood accounted for just $7.6 \%$ of the total available animal protein in the U.S. in 2009 (FAO, 2011). Again by comparison, seafood provides $21.3 \%$ of the total available protein in China, $22.6 \%$ in Japan, and $14.3 \%$ in Norway, with proportions that can be even higher in smaller and developing coastal or island nations (FAO, 2011). However, given that 39\% of Americans live on or near the coast (National Oceanic and Atmospheric Administration, 2013), and that Americans currently consume only half as much seafood as is recommended in the USDA's latest nutrition guidelines, we argue that there is an opportunity for finding ways to meet goals for community sustainability and food security by incorporating innovative seafood harvesting and marketing strategies into local food movements.

Seafood consumption worldwide is higher than ever, however, with ramifications for the sustainability of the world's fisheries. As such, when fisheries are discussed in the various literatures on food systems and food security, they tend to be cast in a negative light, with the emphasis on concerns such as human population growth, the overallocation and depletion of ocean fisheries, and the impacts of aquaculture on ecosystem health (FAO, 2010; Godfray et al., 2010; Hilborn, Stewart, Branch, \& Jensen, 2012; Pauly, Watson, \& Alder, 2005). While this is an important body of research in that it highlights the ubiquitous, and perhaps even pernicious, unsustainability of industrial fishing, a shortcoming is the assumption that human needs (e.g., food security) are necessarily at odds with the sustainability of the world's fisheries and marine ecosystems (Loring, 2013; Loring \& Gerlach, 2010). In other words, fisheries are more commonly construed as a part of the world's foodsecurity problem rather than as part of its possible solutions.

That said, however, there is some fisheries research that is conducted under the rubric of common pool resources and co-management that offers a compelling case for envisioning seafood systems not as part of a global food security "problem," but rather as a part of effective local solutions (e.g., Cinner et al., 2012; McClanahan \& Cinner, 2011). In the work by Cinner and his colleagues, for example, the various challenges posed by climate change to coral reef ecosystems in Madagascar and Papua New Guinea are explored, with the focus on declining coral reef fisheries and the impacts of such declines on artisanal fishing communities. What they find is that local and comanagement of small-scale fisheries can foster winwin scenarios, with marine ecosystems conserved and local artisanal livelihoods strengthened (Cinner et al., 2012). While they do not use the language of food security or food systems per se, their work nevertheless underscores the potential for using small-scale and artisanal fisheries to support sustainable food systems, coastal community development, and fisheries conservation.

As we discuss below, there is the potential for small-scale community fisheries to be important components of local food movements in the U.S. Currently, half the seafood consumed in the U.S. is produced through industrial aquaculture, and the other half is wild-caught. Virtually all of it, however, comes to U.S. consumers through global markets and large-scale processing and distribution networks dominated by a few large corporations, and in this way the seafood system functions in much the same way as does the industrial agriculture and food system (Anderson \& Fong, 1997; Hébert, 2010). As an alternative, local seafood is an avenue by which communities and regions can divest from, or at least reduce their dependence on, the industrial food system by choosing local options (after Kloppenburg, Hendrickson, \& Stevenson, 1996). Likewise, seafood also "fits the bill" for many of 
the values that are commonly attributed to local food systems. For example, wild-caught seafood is generally healthy, nutritious, and safe, although the problem of industrial pollutants in some waters can be an important caveat (Kris-Etherton, Harris, \& Appel, 2002). Pacific salmon, one example that is relevant in Alaska as well as for much of the Pacific Rim, has favorable omega-3 fatty acid and macronutrient profiles that both enhance dietary quality and also buffer against contaminants like methylmercury (Loring, Duffy, \& Murray, 2010; USDA, 2011).

Development of a local seafood industry can also be consistent with the goals of improved environmental conservation and sustainability. The assumption is that locally oriented food systems connect participants more closely to their environments, enabling them to be better stewards (Sundkvist, Milestad, \& Jansson, 2005). Pacific salmon, again a relevant example, is at the center of multiple environmental debates and reforms in the U.S., including the Pacific Northwest region where salmon are a motivating force behind the removal of dams and the restoration of riverine habitats (Hawley, 2011; Klingle, 2007; Wolf, \& Zuckerman, 2003). Likewise, in Alaska salmon are powerful symbols in ongoing debates over logging in the Tongass National Forest and gold and copper mining in the Bristol Bay watershed (Lempinen, 2011).

Finally, when describing local food systems, opportunities, and options, Trivette (2012) emphasizes the important element of intentionality: that local food should be "intended for consumption within the same area that it is produced...rather than simply incorporating food that is available in a particular area" (p. 5). Admittedly, seafood as most Americans currently procure it does not necessarily meet this requirement; commercial seafood is not produced locally in the same sense that agricultural products are, but rather is caught in the open ocean, often far away from shore. However, the concept of locality, for example through regional branding, is already a powerful symbol in many seafood markets (Andreatta, Nash, \& Martin, 2011; Knapp, Roheim, \& Anderson, 2007). Likewise, fisheries are important and key frames of reference for the cultural identity of many coastal communities; the entire Pacific Northwest region of the U.S. has been dubbed "Salmon Nation" in acknowledgement of the multifaceted role that various salmon species play in place-based cultures and traditions there (Wolf and Zuckerman, 2003). Other U.S. coastal areas also relate closely with their fishing activities and traditions, and marketing strategies for seafood products commonly feature the specific communities where the products are landed, as with Maryland blue crab, Maine lobster, and Copper River Red salmon (Acheson, 1997; Mccay, 1981; Paolisso, 2007). And, as we describe in more detail below, intentional participation in fisheries in Alaska by individuals for the sake of self-sufficiency and eating locally is also quite common.

\section{Food Security and Food Systems in the North}

We were specifically interested with this research in exploring the conditions under which access to locally caught seafood contributes to household food security in Alaska. Food security is most commonly defined as whether or not people have equitable physical and economic access to sufficient and safe foods (e.g., World Food Summit, 1996). In the context that we use it here, food security describes more than merely whether sufficient food is being produced, or a one-sizefits-all food-nutrition relationship, and incorporates all of the various ways in which a food system supports health in its various biophysical, social, and ecological dimensions (Loring \& Gerlach, 2009). These include matters such as the importance of certain foods, food choice, local perceptions of hunger, uncertainty and worry about food safety or shortages, and any other psychosocial, sociocultural, or environmental stresses that result from the process of putting food on the table (S. Maxwell, 2001). In rural, predominately Alaska Native communities, for example, wild fish and game are important for food security, not just because they are readily available, but also because they are important to the preservation and transmission of traditions and cultural practices, for the maintenance of social networks and interpersonal relationships, and for supporting individuals' sense 
of self-worth and identity (Fienup-Riordan, 2000;

Loring \& Gerlach, 2009).

Yet food insecurity in Alaska and the North American Arctic is a rising challenge (Caulfield, 2002; Egeland, Pacey, Cao, \& Sobol, 2010; Ford, 2009; Loring \& Gerlach, 2010). According to the United States Department of Agriculture (USDA), Alaska currently has a food-insecurity rate of $14.5 \%$, which is lower than the nationwide average of 16\% (Coleman-Jensen, Nord, Andrews, \& Carlson, 2011). However, rates are much higher for rural communities, and the nonprofit group Feeding America (2011) estimates that some rural parts of the state presently experience food insecurity rates as high as $30 \%$, with children among those most affected. People in many rural Alaskan communities are experiencing a "nutrition transition," whereby the use of traditional country foods is declining and is being replaced with market foods that, while readily available, are both expensive and generally poor in nutritional quality by comparison (H. V. Kuhnlein, Receveur, Soueida, \& Egeland, 2004). Consistent with this transition, Alaskans are increasingly experiencing a host of diet-related health problems, including but not limited to higher incidences of colorectal cancer, obesity, and diabetes (Fenaughty, Fink, Peck, Wells, Utermohle, \& Peterson, 2010; McLaughlin, Middaugh, Utermohle, Asay, Fenaughty, \& Eberhardt-Phillips, 2004), as well as a variety of chronic psychological and psychosocial problems such as domestic violence, alcoholism, depression, and drug abuse (Alaska Department of Health and Social Services [AKDHSS], 2011a). While direct causality among one or more of these dietary changes and health trends is difficult to pin down, the consensus among health researchers, practitioners, and local people is that the solution to these problems is best situated in local food system reform and revitalization (Arnold \& Middaugh, 2004; Hassel, 2006; H. Kuhnlein et al., 2007; Nabhan, 1990).

Part of the challenge with respect to food security in Alaska relates to the limited nature of the state's food system. Despite active local food movements in many parts of the state (Garcia, 2012), only an estimated 3\% to 5\% of agricultural products consumed in Alaska are produced in
Alaska. Agricultural production is limited by a variety of factors, not least of which is a paucity of farms, farmers, and in-state infrastructure for food processing and distribution (Hanna et al., 2012; Paragi, Gerlach, \& Meadow, 2010). Similarly, while the commercial seafood industry is robust and thriving, providing $50 \%$ of U.S. wild landings (NMFS, 2010), very little of this commercial catch is marketed in Alaska, and is instead fed into national and global seafood markets. Specifics are rare regarding the quantity and origin of seafood that is actually consumed directly by Alaskans (Hanna et al., 2012), but even in the iconic fishing communities featured in this research, most grocers do not offer a fresh seafood counter. Recently, noticeable disparities in who benefits from Alaska's commercial fisheries has led some to question the social-justice implications of their widespread reputation of sustainability (Loring, 2013; Richmond, 2013).

Other, noncommercial fisheries in Alaska include sport fisheries and personal use (subsistence) fisheries. ${ }^{1}$ The former are managed as recreational in nature, allow only a limited daily catch, and are open to any participant; the latter are open only to state residents and are generally defined as for personal consumption and not for sale, barter, or trade. These noncommercial fisheries are highly valued by Alaskans, yet their overall contribution to the statewide food system and the extent to which all Alaskans enjoy equal ability to participate in these fisheries remain unclear.

\section{Research Area and Methods}

During the winter of 2011 we were approached by representatives of two community groups in the study region (figure 1), the Kachemak Bay Research Reserve (KBRR) and MAPP of the Southern Kenai Peninsula (MAPP-SKP, formerly the Southern Kenai Peninsula Communities Project), and asked to give a public presentation on food security. Food security emerged as a priority for these groups as a result of a multiyear strategic

\footnotetext{
${ }^{1}$ In Alaska, the word "subsistence" is legally defined and commonly attributed to uses of fish and game by Alaska Natives, although the state constitution ensures equal access to fish and game on state land for all state residents.
} 
Figure 1. Map of the Kenai Peninsula Region of Alaska. Major communities referred to in text are shown.

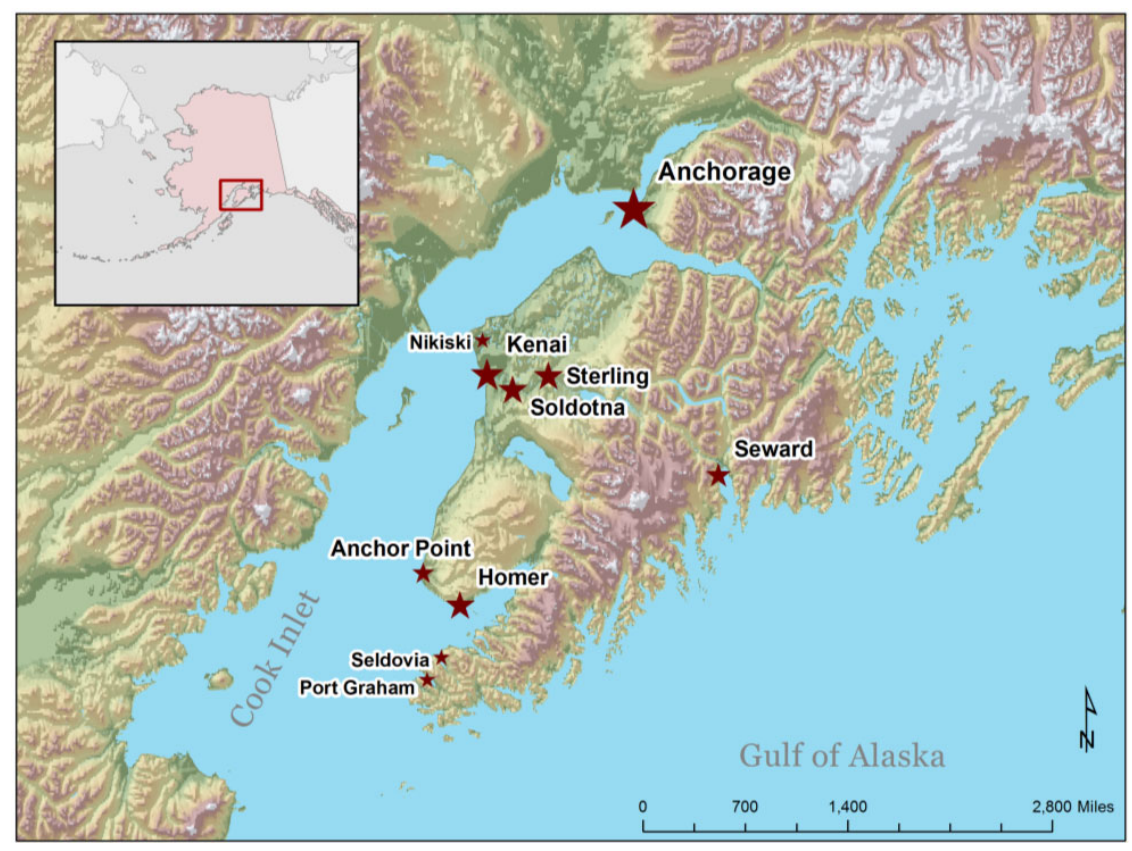

The Kenai Peninsula is well known among Alaskans and tourists from outside the state for its productive salmon and halibut fisheries. Cook Inlet is a stretch of ocean that reaches 180 miles north from the Gulf of Alaska, along the west coast of the Kenai Peninsula, to the city of Anchorage. The associated watershed covers approximately 47,000 square miles $(122,729$ square kilometers) of the southcentral portion of the state. It is home to all five species of Pacific salmon as well as over 400,000 Alaskans, more than half the population of the state. About 50,000 people live on the Kenai Peninsula itself, a land mass about 16,000 square planning project that utilized the Mobilizing for Action through Planning and Partnerships (MAPP) framework. ${ }^{2}$ During our visit, we also participated in two informal focus groups with representatives from KBRR and MAPP-SKP, as well as with other interested community members that included nurses and other community health practitioners, commercial fishermen, and representatives from the group Sustainable Homer. From these discussions one specific theme emerged: frustration with a lack of access to locally caught seafood. Participants described how if one does not fish for himor herself, or does not know someone who fishes, it is extremely difficult to procure affordable, locally caught fish such as salmon and halibut. One important outcome of these meetings is unanimous support for research that evaluates access to local seafood and its role in food security, in order to identify both barriers to and opportunities for strengthening this component of the local food system.

\footnotetext{
${ }^{2}$ For more information on the MAPP process, which is not discussed here, see the National Association of County and City Health Officials' website at http://www.naccho.org/ topics/infrastructure/mapp/index.cfm
}

miles (41,440 square kilometers), or half the size of Maine. Communities include the iconic fishing ports of Homer, Seward, Kenai, and Soldotna, as well as smaller, predominately Alaska Native and Russian communities, including Port Graham, Nanwalek, and Seldovia, which are not accessible by road in spite of their relative proximity to large urban centers.

In addition to local support for this research, the Kenai Peninsula provides an effective and strategic case study location because many of the sociocultural, economic, ecological, and geopolitical circumstances and challenges found here are arguably representative of those found statewide. Though the region suffers from something of a reputation for affluence among many Alaskans, there are nevertheless many similarities in vital statistics among this region and the state as a whole (table 1). Per capita income, percent of the population below the poverty level, and food security rates, for example, all match statewide numbers. Additional parallels between the Kenai Peninsula and the state as a whole also exist: the region is home to communities that are on and off of the road system; renewable-resource industries such as fishing and tourism are hugely important, as are 
Table 1. Comparative Details for the Kenai Peninsula and the State of Alaska

\begin{tabular}{|c|c|c|}
\hline Vital Statistics $^{a}$ & Kenai Peninsula & Alaska \\
\hline Population & 56,293 & 722,718 \\
\hline \multicolumn{3}{|l|}{ Demography } \\
\hline Caucasian & $85.0 \%$ & $67.9 \%$ \\
\hline African American & $0.6 \%$ & $3.6 \%$ \\
\hline Alaska Native/American Indian & $7.5 \%$ & $14.9 \%$ \\
\hline Asian & $1.2 \%$ & $5.6 \%$ \\
\hline Native Hawaiian & $0.3 \%$ & $1.1 \%$ \\
\hline 2+ Races & $5.4 \%$ & $7.0 \%$ \\
\hline Unemployment ${ }^{\mathrm{b}}$ & $9.3 \%$ & $7.6 \%$ \\
\hline Food Insecurity ${ }^{c}$ & $14.7 \%$ & $14.6 \%$ \\
\hline Children & $20.4 \%$ & $19.9 \%$ \\
\hline Per Capita Income & US\$29,127 & US\$30,726 \\
\hline Below Poverty Level & $9.5 \%$ & $9.5 \%$ \\
\hline \multicolumn{3}{|c|}{$\begin{array}{l}\text { b Unemployment data from the State of Alaska Department of Labor and Workforce Development } \\
\text { Research and Analysis website, http://laborstats.alaska.gov/, retrieved 09/12/2012. } \\
\text { c Food insecurity rates are from Feeding America's Map the Meal Gap model, } \\
\text { http://feedingamerica.org/hunger-in-america/hunger-studies/map-the-meal-gap.aspx, retrieved } \\
07 / 12 / 2011 \text {. }\end{array}$} \\
\hline
\end{tabular}

selected and that they should expect a survey soon. With the survey we also included a one dollar bill as a token of appreciation. To further raise awareness of the study, we also arranged interviews on Kenai Peninsula public radio stations.

Respondents were asked to report if someone in their household fishes, and if so, to specify whether this includes fishing commercially, fishing for sport, fishing as a guide or charter, and/or fishing for personal use or subsistence. Next, they were asked to report if they consume locally caught fish or other seafood; for those with a positive response, several questions followed regarding how and where they obtain the seafood, that is, whether they fish for it themselves, purchase it at a local retailer, barter or trade for it, or receive it as a gift. We also asked about seafood consumption rates during the fishing season (defined as late May through September) and outside the fishing season (October through May), with options including: frequently (almost every day), sometimes (2-5 times per week), rarely (once or fewer times per week), and never. We also asked about fish waste, querying households whether at the beginning of the fishing season they had any seafood from the previous year, and if so, what they did with it (e.g., smoke or can it, feed it to dogs, give it away, throw it away, etc.).

To measure food security, the survey also included six questions about "coping strategies" (after D. G. Maxwell 1996; D. G. Maxwell, Ahiadeke, Levin, Armar-Klemesu, Zakariah, \& Lamptey, 1999), which ask respondents to report how often in the last month they have taken actions such as reducing meal size or skipping meals because there is not enough food and/or so that someone else in their household can eat
${ }^{3}$ A random number generator was written in the statistical software package R (R Development Core Team, 2011) to select addresses from the list. 


\section{Table 2. Coping Strategies Questions}

These six questions are intended to get at a range of possible coping strategies among respondents. The weights indicate relative severity of the strategy and are used as part of the calculation of the final score. Maxwell et al. (1999) recommends using focus groups to determine the most appropriate weighting, but funding limitations required us to set weightings based on the relative severity of dietary pattern disruption. Note that we do include a question on food preference (Q1), and weigh borrowing money for food (Q3), a strategy often associated with significant psychological stress, more than a modest portion reduction (Q2).

Question

1. In the last month, how often have you and your household eaten foods that are less preferred in order to make sure that everyone in the household could eat?

2. In the last month, how often has someone in your household had to limit their portion size in order to make sure everyone in the household could eat?

3. In the last month, how often have you had to borrow food, or borrow money to buy food, so that everyone in the household could eat?

4. In the last month, how often have you or another adult in your household limited their portion size specifically so that a child could eat?

5. In the last month, how often have you or anyone else in your household had to skip a meal because there was not enough food?

6. In the last month, how often have you or anyone else in your household gone an entire day without eating because there was not enough food?

(table 2). Frequencies allowed were: never (worth 4 points), rarely (once or fewer times per week, worth 3 points), sometimes (2-5 times per week, worth 2 points), and frequently (almost every day, worth 1 point). The monthly recall duration was chosen to in order to gauge food security at the time during the year that locally caught seafood is most likely being utilized; surveys were distributed at the end of September, and major salmon fishing activities in the region end in August.

One of the reasons we selected this coping strategies protocol is because it does not rely on prescriptive definitions of food security or insecurity, and as such is more accommodating to the less quantifiable social and cultural dimensions of food security (D. G. Maxwell 1996; D. G. Maxwell et al. 1999). Multiple variations of this protocol have been implemented and validated in different settings (e.g., Coleman-Jensen et al., 2011; USDA 2001b), although their appropriateness for Alaskan settings, and especially remote communities, is questionable. For example, the USDA (2011b) food insecurity protocol focuses on the availability of money to buy food, but in Alaska subsistence foods play an important role for households in both rural and urban settings (Bersamin, Sidenberg-Cherr, Stern, \& Luick, 2007; Fazzino \&
Loring, 2009). Likewise, the USDA protocol also invokes the concept of a "balanced" diet, but this could be confusing to many in Alaska since foodways here are traditionally flexible and highly seasonal in nature (Wolfe \& Bosworth, 1990). Likewise, use of the word "balanced" could lead some respondents to self-assess against their perceptions of government standards for nutrition, rather than in terms of their own traditions, preferences, and conceptions of health. As such, our six chosen questions focus primarily on food preference and disruption of meal patterns as cross-culturally relevant domains of food insecurity (after Coates, Frongillo, Rogers, Webb, Wilde, \& Houser, 2006).

Responses to these six questions are tallied in such a way as to create a single, unit-less score in the range of 11 to 44 , with 11 being food insecure and 44 being completely food secure. The formula for calculating food security is shown below:

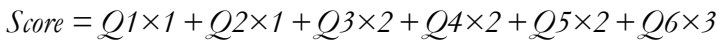

We loosely define food insecurity as a score falling below 40, as this score indicates that respondents are enacting at least two of the lowest-weighted coping strategies, and or one or more of the more disruptive strategies. Note also that this scale is 
intentionally not adjusted to begin at zero out of recognition that more severe forms of food insecurity and hunger are possible than can be captured by this instrument.

Other questions on the survey addressed household composition, income level, opinions regarding the sustainability of local fisheries, and whether respondents rely on some form of nutritional assistance such as the Alaska Food Stamp Program or the Special Supplemental Nutrition Program for Women, Infants, and Children (WIC).

\section{Results}

Of the 1,500 surveys mailed, 490 responses were received and 75 were returned as undeliverable, for an adjusted response rate of $34.38 \%$ and a confidence level greater than $95 \%$ that the sampled population is representative of the population of the Kenai Peninsula at large (Krejcie \& Morgan, 1970). While the response rate for our survey $(34.38 \%)$ is modest, and just below the Center for Disease Control and Prevention's low target of 40\% for Alaska (AKDHSS, 2011b), our data for vital statistics such as household income distribution and food assistance rates match known statistics for the region, suggesting that our sample does not have a reporting bias (Dey, 1997). For example, median household income in 2010 in the Kenai Peninsula Borough according to the state of Alaska was US $\$ 57,000$, and in our study, the median response fell in the US\$50,000-US\$75,000 range. Likewise, $11.8 \%$ of our respondents report receiving food assistance, which is on par with the state reported rate in 2011 of $11.2 \%$ (USDA, 2013).

We find that fishing and the consumption of seafood are both extremely common in the Kenai Peninsula. Nearly $95 \%$ of respondents report at least some access to local seafood, and $80 \%$ of survey takers report that someone in their household fishes, the majority of whom $(66.5 \%)$ describe their primary fishing activities as for personal use and subsistence. Sport fishing is the next most common kind of fishing ( $42 \%)$, followed by a much smaller group of commercial fishers $(7 \%)$ and guide/charter operators $(2 \%)$. When asked to

describe the role of salmon in their household, $67 \%$ report that it is an important part of their diet, $24 \%$ respond that it is an important part of their financial security, and $55 \%$ report that salmon are important to their community and/ or culture.

Fishing is not the only way that Kenai Peninsula residents obtain local 
Table 3. Comparison of Food-Security Scores Among Households With and Without Access to Locally Caught Seafood

\begin{tabular}{lcccc}
\hline Household Income & $\begin{array}{c}\text { Food Security Score, } \\
\text { With Fish }\end{array}$ & $\begin{array}{c}\text { Food Security Score, } \\
\text { Without Fish }\end{array}$ & Difference & $\mathrm{p}$ \\
\hline >US $\$ 25,000$ & 39.19 & 36.32 & $2.87^{*}$ & $<0.01$ \\
US $\$ 25,000$-US $\$ 50,000$ & 39.42 & 38.23 & 1.19 & 0.16 \\
US $\$ 50,000-U S \$ 75,000$ & 42.15 & 42.93 & -0.78 & 0.26 \\
US $\$ 75,000-U S \$ 100,000$ & 43.32 & 43.42 & -0.10 & 0.77 \\
$>$ US $\$ 100 \mathrm{~K}$ & 43.53 & 42.75 & 0.78 & 0.38 \\
\hline All & 41.30 & 39.31 & 1.99 & \\
\hline ANOVA & $\mathrm{F}=25.9$ & $\mathrm{~F}=16.02$ & \\
\hline Correlation & 0.50 & 0.71 & \\
\hline
\end{tabular}

seafood, however. While $62 \%$ of respondents describe fishing as their primary method of obtaining local seafood, $23 \%$ report that sharing is the most common way they procure it. Very few of those with access to local seafood, between $2 \%$ and $5 \%$, obtain this through one of the other means, such as purchasing local fish direct from a commercial fisher or purchasing from major or local grocers. This aligns with our observations and local complaints regarding the lack of local venues for purchasing locally caught seafood. Regarding the $5 \%$ of households without any access to local seafood, just over half (54\%) are households in the US $\$ 25,000$-US $\$ 50,000$ income bracket, while $29 \%$ are in the US\$50,000-US\$75,000 bracket, and 17\% are in the lowest $(<\mathrm{US} \$ 25,000)$ bracket. No households at higher income levels report not having access to local seafood.

We also explored how procurement strategies vary by the respondent's socioeconomic details, and found a compelling, if not terribly surprising pattern (figure 2). Two-way ANOVA shows that household income has a statistically significant influence on the means by which survey takers report procuring local seafood $(p<0.01)$. Fishing, sharing, and barter/trade are found to be the primary sources of this variance. In other words, more low-income households rely on sharing as their primary source of locally caught seafood than do households at higher income levels, and conversely, more high-income households rely on fishing as their primary source of locally caught seafood than do lower-income households. We also find that barter and trade of local seafood, which is different from sharing in that it describes an explicit component of fair exchange of goods and services, is the primary method by which $10 \%$ of respondents at the lowest income level procure local seafood. This is notably higher than reported by respondents at all other income levels.

\section{Food Security and Local Seafood}

We find that $27 \%$ of respondents have a food security score lower than 40 , and only $39 \%$ of respondents achieve a perfect score of 44 . One specific hypothesis that we aim to test with this research is that there is a positive relationship between food security and access to locally caught seafood. In other words, we propose that households with access to locally caught seafood have greater food security than do those households that do not. To test this hypothesis, we first used a twotailed Students T-test (table 3), and find a statistically significant increase in the mean food security score for those with access to locally caught seafood, but only at the lowest income bracket. Research shows, however, that household income and food security are likely to share a positive relationship (e.g., Kent, 1997), meaning that households with higher incomes also are likely to be more food secure. Indeed, our data show a weak ( $\mathrm{r}$ $=0.50$ ) overall correlation in the population between food-security score and income. To test access to local seafood as an intervening variable, 
we also temporarily removed from the sample population those low-income households who report having access to local fish, ${ }^{4}$ and then tested again for a correlation between food-security score and household income for this adjusted sample. Our hypothesis is that if access to locally caught fish has no intervening effect on the food-security score for low-income households, the strength of the overall correlation between food security and income should not change. We do find that the correlation coefficient between food-security score and household income increases $(\mathrm{r}=0.71)$ when the low-income households with access to local seafood are excluded from analysis.

We also looked at how food-security scores vary by reported local seafood consumption frequencies during and outside of the fishing season. No statistically significant difference from the mean food-security score is found for those responding that they eat seafood frequently, sometimes, or rarely, but those who report never eating local seafood had an average score of 36, which is significantly lower than the mean for the Kenai Peninsula as a whole.

Regarding fish waste, $65.4 \%$ of respondents report having some fish left over from the previous year when the new fishing season begins. Of those, $30 \%$ smoke, can, or otherwise preserve it; $28.1 \%$ give it away; $17.6 \%$ use it for dog food; $11.9 \%$ donate it; $6.7 \%$ throw it away; $4 \%$ compost it; and $1.7 \%$ trade or barter with it.

Regarding the sustainability of Cook Inlet salmon fisheries, respondents are largely divided, with 35.02\% responding 'Yes,' $18.57 \%$ responding 'No,' and $46.41 \%$ responding 'Not Sure.' Handwritten comments made by many survey takers in association with this question provide additional details regarding people's answers. A total of 125 respondents provided comments spanning a variety of topics, including mistrust of management, political influence on management, ecological observations, overallocation, and concerns

\footnotetext{
${ }^{4}$ We cannot test for a correlation between food-security score and household income for just those households without access to local seafood because this accounts for only $5 \%$ of our sample, and almost exclusively households at the two lowest income levels.
}

regarding social justice. The two most common concerns are a mistrust of the management process (31 mentions), and concerns about the status of King salmon (30 mentions). Also noteworthy is a group of comments (35 mentions) that identify a specific group of fishers - commercial, personal use, or sport - as receiving an unfair allocation of the catch, and/or being specifically responsible for problems with the sustainability of the fisheries.

\section{Discussion}

The data described above confirm that there is a robust local seafood component in the Kenai Peninsula food system, and also suggests that access to local seafood improves food security in the Kenai Peninsula, most notably for low-income households. The latter finding is more encouraging than it is surprising; as we discussed earlier, the notion that local food systems can provide better food security outcomes is often an explicit objective of local food movements. Still, to our knowledge this research is among the first to provide empirical evidence in support of such an argument. Also noteworthy is our finding that the widespread use of local seafood does not appear to contribute significantly to food waste, which is an emerging and important issue for food systems and security research (Abdulla, Martin, Gooch, \& Jovel, 2013).

However, we also find that a majority of local Kenai Peninsula residents, especially those at higher income levels, are harvesting local seafood themselves, while many households at lower income levels rely on alternative means, including but not limited to sharing, barter, and trade. This is noteworthy because it is illegal in Alaska to barter or trade with seafood obtained in sport and personaluse fisheries, implying that at least part of the local population has to resort to illicit means to achieve food security. Thus, the frustrations communicated to us by our local partners are neither isolated nor anecdotal, but rather are representative of a systemic shortcoming of the Kenai Peninsula's food system: while many rely on local seafood, some must do so creatively while others simply cannot.

It is noteworthy that there appears to be a gap in access to local seafood not at the lowest income bracket, but for those in the US $\$ 25,000$ US $\$ 50,000$ range, a bracket which has a lower than 
average food-security score, but for which we do not find a significant effect of access to local fish on food security. A possible explanation involves food stamp eligibility; recipients of food stamps in Alaska are allowed to use these for the purchase of fishing equipment and supplies. It is possible that some of the households at that income level either do not qualify for food stamps despite their need, or they have negative or ambivalent perceptions of food assistance programs that keep them from taking advantage of the support (Daponte, Sanders, \& Taylor, 1999).

What is missing from the Kenai Peninsula food system, we further argue, is a system of distribution and marketing that brings local seafood to local consumers at an affordable price, an assertion that refers back to the Trivette (2012) comment noted earlier: that "local food" entails more than simply eating food that is locally available, but rather must also involve a system through which local foods are produced and marketed with the intention that they reach local consumers. Alaskans take great pride in having a reputation for independence and self-reliance, but the case of the Kenai Peninsula shows that the regulatory framework for supporting this independence is designed around people feeding themselves, and as such, people without the ability, time, resources, or inclination to do so are left out. There are some inroads in the region for the development of local and regional seafood markets that are more accessible to people who currently lack the means to procure seafood. Locally caught fish are sporadically available at the Homer Farmers' market, for example, and this is venue accepts both WIC and food stamps. Charter business operators sometimes donate seafood that has been left unclaimed or unwanted by their clients to regional food banks as well (L. Swarner, personal communication, June 21, 2011), but this obviously does not provide a reliable or predictable source of food. We have also heard reports of some local commercial fishers experimenting with direct and local marketing, for example, community supported fishing or "CS-Fish." 5

A question remains, however, as to why more robust local markets for local seafood do not

\footnotetext{
${ }^{5}$ For example, see http://thealaskatrust.org/alaskans-own.php
}

already exist if there is indeed a large but as yet unmet demand. Unlike agriculture in Alaska, the development of which is stalled in part by a lack of infrastructure (Gerlach \& Loring, 2012), the Kenai Peninsula is already home to a number of small, seasonally operated businesses oriented around processing, packaging, and shipping seafood, although these are geared toward providing services to individual customers such as tourists rather than commercial markets. Anecdotally, fishers have provided us with a number of possible explanations for the lack of local marketing: some do not perceive demand as being sufficient because so many Alaskans fish for themselves; others explain that commercial fishing is a labor-intensive occupation that involves long days and little free time, such that fishers would need dedicated business partners to make such activities manageable and profitable; and others still cite difficult and expensive food-safety regulations and permitting requirements by the state of Alaska.

This is an issue of food policy and one that bears additional discussion and research, as working within the confines of one-size-fits-all food-safety policies has been a challenge for smallscale producers throughout the U.S. (Salatin, 2007). In Alaska, relevant policies address permitting and inspection of processing facilities and waste management practices by Alaska's Department of Environmental Conservation (Alaska Code 18 AAC 34), even when only minimal processing, such as removing the head and viscera ("heading and gutting”), is involved. Similarly, grocery store owners and managers across the state have reported to us that record-keeping requirements for traceability of fresh fish related to the U.S. Bioterrorism Act of 2002 and the U.S. Food Safety Modernization Act of 2010 are too burdensome for them to consider sourcing and selling local fish. Whether these and other relevant policies and regulations are indeed unnecessarily onerous designed for large-scale industrial operations and as such prohibitively cumbersome or expensive for small-scale entrepreneurs - or whether these perceptions can be addressed with proper training remains to be evaluated, although some training and guidance materials on these policies is already available (e.g., Johnson, 2007). 
An argument can be made, however, that policies could do more to support local food security and sovereignty through formal and informal local seafood markets, evidenced by the fact that so many respondents report obtaining fish through barter and trade, which as we note above, is currently illegal if these fish are obtained via personal use or sport fisheries. We speculate that the administrative categories that define (and delineate) personal use, sport, and commercial fisheries may be too inflexibly or indelibly drawn to allow for innovative solutions. For example, state and federal management agencies currently recognize only one class of commercial fishing, and the majority of these fisheries in Alaska are managed with tradable quotas or permits or some other such system for limited entry that are designed around large-scale, industrial fishing activities. Thus entry into these fisheries can be cost-prohibitive for new smallscale operators, and as such market forces arguably favor participation in global over local markets, especially for highly valued food fisheries such as those common in Cook Inlet. This is a challenge facing rural food systems across the world (Rosset, 2008), and policy solutions that instead favor food sovereignty continue to be elusive. One possible solution that might be explored is the creation of an artisanal class of commercial fishing that could be regulated independently from large-scale commercial fishing as a way to reduce the cost of entry and promote profitable small-scale fishing for local markets. If food sovereignty is the goal, creation of such a fishery would be an effective policy action in that direction.

\section{On Sustainability}

One final point of interest regarding the survey findings is that survey respondents were divided on the matter of the sustainability of Cook Inlet salmon fisheries. While perhaps not surprising to Alaskans who are quite aware of the region's reputation for conflict over fisheries, the findings are somewhat surprising with respect to the purported goals of local food movements. As stated earlier, one of the many assumptions made about local food systems is that they more closely connect people with the resources on which they depend, resulting in more sustainable outcomes.
However, while participation in and reliance on local seafood are extensive across the Kenai Peninsula, confidence and expertise regarding the status of these resources is not. We speculate that this is related to ongoing political issues surrounding how local salmon fisheries are presently managed and allocated, but suggest also that this might be related to the individualistic nature of the current seafood harvesting regime. Commercial fishers often possess high quality ecological information about the status of fisheries, but personaluse fishers, by comparison, do not necessarily have the same opportunities for, and/or level of engagement with, fisheries, and therefore have less opportunity to develop informed ecological opinions (Loring, Harrison, and Gerlach, in press).

Concerned consumers, too, have limited access to information about ecosystem conditions and the sustainability of fishing practices, which accounts for the emergence of eco-labeling initiatives by groups such as the Marine Stewardship Council and the Alaska Seafood Marketing Institute. These programs are valuable, but their motivations are not always transparent and their standards do not necessarily align with the values sought out by consumers (Hébert, 2010; Loring, 2013). Improved local markets may also serve as an important mechanism for facilitating greater social engagement with and communication among commercial fishers and consumers, with the anticipated outcome being that consensus and awareness regarding environmental sustainability issues will improve. This notion is similar to the rationale behind the "know your farmer" movements, ${ }^{6}$ situating local artisanal fishers not just as harvesters of local seafood, but also as respected observers and sentinels of marine ecosystems who can be held responsible for unsustainable or unsafe practices by their neighbors. We currently have ongoing ethnographic research with participants in these and other area fisheries to better understand how locals are informing their perceptions regarding sustainability.

\footnotetext{
${ }^{6}$ For example, see the USDA's Know Your Farmer, Know Your Food program at http://www.usda.gov/wps/portal/ usda/knowyourfarmer?navid=KNOWYOURFARMER
} 


\section{Limitations of the Study}

We recognize that food insecurity and other socioeconomic circumstances may be clustered in certain communities, and that the by-mail survey method may result in underreporting for some the peninsula's smaller cultural groups such as the Russian Old Believers, for whom fishing is a hugely important livelihood strategy. Lack of funding precluded us from implementing a more aggressive survey distribution that would have provided more powerful data at the community or neighborhood level. As noted earlier, our response rate was slightly lower than hoped, but our results nevertheless suggest that we do not have a small sample bias. This being said, we are also aware that this research may not adequately represent the challenges faced by Alaska's homeless, itinerant, or otherwise dispossessed peoples.

Regarding the discussion of fish waste, there may be a self-reporting bias in our data, but the pattern of fish use is likely accurate. Also, Maxwell et al. (1999) note that the coping strategies protocol may overestimate the number of food-insecure households. As noted, however, the survey was distributed in the early fall with a one month recall period, the time of year that food security for those who rely on fisheries is arguably at its highest.

Finally, due to limited resources we did not engage formal focus groups to determine the most appropriate weightings for the six coping strategies question. Instead, we selected questions that focused primarily on dietary disruption and selected conservative weightings when calculating foodsecurity scores.

\section{Conclusions}

At the core of all local food movements is a desire among people to take control of their food systems, whether done under the heading of health, food security, food sovereignty, sustainability, or some other ideal. Many Alaskans already enjoy a fair amount of control over their diets, thanks in part to the liberal opportunities in the state for the personal-use harvest of wild fish and game, and in part to a frontier mentality that emphasizes selfreliance and libertarian values. Yet some in Alaska do not enjoy these same opportunities, among whom are the many people experiencing the nutrition transition described earlier. Our data for the Kenai Peninsula provide evidence that the individualistic strategy for food procurement common in Alaska contributes to food security for some, but shortcomings for many remain. The widespread uncertainty among locals about the status of Cook Inlet fisheries and the widespread reliance on ostensibly illegal barter and trade for the lowest income levels are two caveats to the self-reliance purported by so many. More disconcerting, however, are the social-justice concerns related to those who do not share in the benefits of these fisheries. As discussed above, our working assumption is that this problem can be addressed through local and regional marketing and policy innovations designed with the explicit intent of bringing commercially caught local seafood to local consumers. The challenges for commercial fishers so inclined to contribute to such an experiment are likely no different than their agricultural counterparts: how to escape the "lock-in trap" of global food commodity markets and regulatory systems that favor industrial business models and economies of scale, while still making a fair living for themselves and their families. What we hope this work has contributed to the discussion of local and small-scale food movements is evidence that, while many around the world are works in progress, their aims and objectives appear both realistic and worthwhile.

\section{References}

Abdulla, M., Martin, R. C., Gooch, M., \& and Jovel, E. (2013). The importance of quantifying food waste in Canada. Journal of Agriculture, Food Systems, and Community Development, 3(2), 137-151. http://dx.doi.org/10.5304/jafscd.2013.032.018

Acheson, J. M. (1997). The politics of managing the Maine lobster industry: 1860 to the present. Human Ecology, 25(1), 3-27. http://dx.doi.org/10.1023/A:1021979718461

Alaska Department of Health and Social Services [AKDHSS]. (2011a). Moving forward, Comprehensive Integrated Mental Health Plan 2006-2011. Anchorage, Alaska: Author. Retrieved from http://dhss.alaska.gov/dph/HealthPlanning/Pages /movingforward/execsumm.aspx 
AKDHSS, Division of Public Health. (2011b). BRFSS

[Behavioral Risk Factor Surveillance System] Methodology. Retrieved from

http://dhss.alaska.gov/dph/Chronic/Pages/brfss/ method.aspx

Anderson, J. L., \& Fong, Q. S. W. (1997). Aquaculture and international trade. Aquaculture Economics \& Management, 1(1-2), 29-44. http://dx.doi.org/10.1080/13657309709380201

Andreatta, S., Nash, B., \& Martin, G. (2011). Carteret Catch $^{\text {TM}}$ : Raising awareness oflocal seafood through community and business partnerships. Human Organization, 70(3), 279-288.

Arnold, S., \& Middaugh, J. P. (2004). Use of traditional foods in a healthy diet in Alaska: Risks in perspective. State of Alaska Epidemiology Bulletin, 8(11), 1-48.

Berry, W. (1982). The unsettling of America: Culture and agriculture. New York: Random House.

Bersamin, A., Sidenberg-Cherr, S., Stern, J. S., \& Luick, B. R. (2007). Nutrient intakes are associated with adherence to a traditional diet among Yup'ik Eskimos living in remote Alaska Native communities: The CANHR Study. International Journal of Circumpolar Health, 66(1), 62-70. http://dx.doi.org/10.3402/ijch.v66i1.18228

Born, B., \& Purcell, M. (2006). Avoiding the local trap: Scale and food systems in planning research. Journal of Planning Education and Research, 26, 195-207. http://dx.doi.org/10.1177/0739456X06291389

Brinson, A., Lee, M.-Y., \& Rountree, B. (2011). Direct marketing strategies: The rise of community supported fishery programs. Marine Policy, 35(4), 542-548. http://dx.doi.org/10.1016/j.marpol.2011.01.014

Caulfield, R. (2002). Food security in Arctic Alaska: A preliminary assessment. In G. Duhaime, Canadian Circumpolar Institute, \& Universite Laval (Eds.), Sustainable food security in the Arctic: State of knowledge (pp. 75-94). Alberta: CCI Press.

Cinner, J. E., McClanahan, T. R., MacNeil, M. A., Graham, N. A. J., Daw, T., Mukminin, A.,... Kuange, J. (2012). Comanagement of coral reef social-ecological systems. Proceedings of the National Academy of Sciences, 109(14), 5219-5222. http://dx.doi.org/10.1073/pnas.1121215109

Coates, J., Frongillo, E. A., Rogers, B. L., Webb, P., Wilde, P. E., \& Houser, R. (2006). Commonalities in the experience of household food insecurity across cultures: What are measures missing? Journal of Nutrition, 136, 1438S-1448S.

Coleman-Jensen, A., Nord, M., Andrews, M., \& Carlson, S. USDA. (2011). Household food security in the United States in 2010 (Economic Research Report No. ERR-125). Washington, D.C.: United States Department of Agriculture, Economic Research Service. http://www.ers.usda.gov/publications/err125/

Daponte, B. O., Sanders, S., \& Taylor, L. (1999). Why do low-income households not use food stamps? Evidence from an experiment. The Journal of Human Resources, 34(3), 612-628. http://dx.doi.org/10.2307/146382

Dey, E. L. (1997). Working with low survey response rates: The efficacy of weighting adjustments. Research in Higher Education, 38(2), 215-227. http://dx.doi.org/10.1023/A:1024985704202

Dillman, D. A. (2007). Mail and Internet surveys: The Tailored Design Method [2007 Update]. Hoboken, New Jersey: John Wiley and Sons.

Egeland, G. M., Pacey, A., Cao, Z., \& Sobol, I. (2010). Food insecurity among Inuit preschoolers: Nunavut Inuit Child Health Survey, 2007-2008. Canadian Medical Association Journal, 182(3), 243-248. http://dx.doi.org/10.1503/cmaj.091297

Evans-Cowley, J. (2011). Evaluating food systems in comprehensive planning: Is the Mississippi Gulf Coast planning for food? Journal of Agriculture, Food Systems, and Community Development, 2(1), 104-126. http://dx.doi.org/10.5304/jafscd.2011.021.009

Fazzino, D., \& Loring, P. A. (2009). From crisis to cumulative effects: Food security challenges in Alaska." NAPA Bulletin, 32, 152-177. http://dx.doi.org/10.1111/j.1556-4797.2009. 01033.x

Feeding America. (2011). Map the meal gap, food insecurity in your county. http:// feedingamerica.org/hunger-inamerica/hunger-studies/map-the-meal-gap.aspx

Fenaughty, A., Fink, K., Peck, D., Wells, R., Utermohle, C., \& Peterson, E. (2010). The burden of overweight and obesity in Alaska. Anchorage, Alaska: Section of Chronic Disease Prevention and Health Promotion, Division of Public Health, Alaska Department of Health and Social Services. http://dhss.alaska.gov/dph/Chronic/Documents/ Obesity/pubs/ObesityBurdenReport 2010.pdf 
Fienup-Riordan, A. (2000). Hunting tradition in a changing world: Yup'Ik lives in Alaska today. Piscataway, New Jersey: Rutgers University Press.

Food and Agriculture Organization of the United Nations [FAO]. (2010). The state of the world fisheries and aquaculture (Technical Report of the Food and Agriculture Organization of the United Nations). Rome: United Nations. Retrieved from http://www.fao.org/docrep/013/i1820e/ i1820e00.htm

FAO. (2011). Fishery and aquaculture statistics (FAO Yearbook). Rome: Author. Retrieved from http://www.fao.org/docrep/015/ba0058t/ ba0058t.pdf

Ford, J. D. (2009). Vulnerability of Inuit food systems to food insecurity as a consequence of climate change: A case study from Igloolik, Nunavut. Regional Environmental Change, 9(2), 83-100. http://dx.doi.org/10.1007/s10113-008-0060-x

Garcia, R. A. (2012). Public use of local foods in the Tanana $V$ alley: Understandings of producers and low-income community members. Fairbanks, Alaska: University of Alaska Fairbanks.

Gerlach, S. C., \& Loring, P. A. (2012). Rebuilding Alaska foodsheds: No shortage of good ideas. Rural Connections, 6(2), 23-24.

Godfray, H. C. J., Beddington, J. R., Crute, I. R., Haddad, L., Lawrence, D., Muir, J. F.,...Toulmin, C. (2010). Food security: The challenge of feeding 9 billion people. Science, 327(5967), 812-818. http://dx.doi.org/10.1126/science.1185383

Hanna, V., Frazier, R., Parker, K., \& Ikatova, I. (2012). Food system assessment. Anchorage, Alaska: Institute of Social and Economic Research, University of Alaska Anchorage.

Hassel, C. A. (2006). Woodlands wisdom: A nutrition program interfacing indigenous and biomedical epistemologies. Journal of Nutrition Education and Behavior, 38(2), 114-120. http://dx.doi.org/10.1016/i.jneb.2005.11.033

Hawley, S. (2011). Recovering a lost river: Removing dams, rewilding salmon, revitalizing communities. Boston: Beacon Press.

Hébert, K. (2010). In pursuit of singular salmon: Paradoxes of sustainability and the quality commodity. Science as Culture, 19(4), 553-581. http://dx.doi.org/10.1080/09505431.2010.519620
Hilborn, R., Stewart, I. J., Branch, T. A., \& Jensen, O. P. (2012). Defining trade-offs among conservation, profitability, and food security in the California current bottom-trawl fishery. Conservation Biology, 26(2), 257-268. http://dx.doi.org/10.1111/j.15231739.2011.01800.x

Johnson, T. (Ed.). (2007). Fishermen's direct marketing manual (4th ed.). Anchorage, Alaska: Alaska Sea Grant.

Kent, G. (1997). Fisheries, food security, and the poor. Food Policy, 22(5), 393-404. http://dx.doi.org/10.1016/S0306-9192(97)00030-4

Kimbrell, A. 2002. The fatal harvest reader: The tragedy of industrial agriculture. Washington, D.C.: Island Press.

Klingle, M. W. (2007). Emerald City: An environmental bistory of Seattle. New Haven, Connecticut: Yale University Press.

Kloppenburg, J., Hendrickson, J., \& Stevenson, G. W. (1996). Coming into the foodshed. Agriculture and Human Values, 13(3), 33-42. http://dx.doi.org/10.1007/BF01538225

Knapp, G., Roheim, C. A., \& Anderson, J. L. (2007). The great salmon run: Competition between wild and farmed salmon. Anchorage, Alaska: UAA Institute of Social and Economic Research.

Krejcie, R. V., \& Morgan, D. W. (1970). Determining sample size for research activities. Educational and Psychological Measurement, 30, 607-610.

Kris-Etherton, P. M., Harris, W. S., \& Appel, L. J. (2002). Fish consumption, fish oil, omega-3 fatty acids, and cardiovascular disease. Circulation, 106, 2747-2757. http://dx.doi.org/10.1161/01.CIR. 0000038493.65177 .94

Kuhnlein, H. V., Receveur, O., Soueida, R., \& Egeland, G. M. (2004). Arctic indigenous peoples experience the nutrition transition with changing dietary patterns and obesity. Journal of Nutrition, 134(6), 1447-1453.

Kuhnlein, H., Erasmus, B., Creed-Kanashiro, H., Englberger, L., Okeke, C., Turner, N.,...Bhattacharjee, L. (2007). Indigenous peoples' food systems for health: Finding interventions that work. Public Health Nutrition, 9(8), 1013. http://dx.doi.org/10.1017/PHN2006987

Lempinen, E. (2011). In fight over Alaskan mine, public interest turns to science. Science, 334, 469-470. 
Loring, P. A. (2013). Alternative perspectives on the sustainability of Alaska's commercial fisheries. Conservation Biology, 27(1), 55-63. http://dx.doi.org/10.1111/j.1523-1739. 2012.01938.x

Loring, P. A., Duffy, L. K., \& Murray, M. S. (2010). A risk-benefit analysis of wild fish consumption for various species in Alaska reveals shortcomings in data and monitoring needs. Science of The Total Environment, 408(20), 4532-4541.

http://dx.doi.org/10.1016/j.scitotenv.2010.07.013

Loring, P. A., \& Gerlach, S. C. (2009). Food, culture, and human health in Alaska: An integrative health approach to food security. Environmental Science and Policy, 12(4), 466-478. http://dx.doi.org/10.1016/i.envsci.2008.10.006

Loring, P. A., \& Gerlach, C. (2010). Food security and conservation of Yukon River salmon: Are we asking too much of the Yukon River? Sustainability, 2(9), 2965-2987. http://dx.doi.org/10.3390/su2092965

Loring, Philip A., Hannah L. Harrison, and S. Craig Gerlach. (in press). Local perceptions of the sustainability of Alaska's highly contested Cook Inlet salmon fisheries. Society and Natural Resources.

Maxwell, D. G. (1996). Measuring food insecurity: The frequency and severity of 'coping strategies.' Food Policy, 21(3), 291-303. http://dx.doi.org/10.1016/0306-9192(96)00005-X

Maxwell, D., Ahiadeke, C., Levin, C., Armar-Klemesu, M., Zakariah, S., \& Lamptey, G. M. (1999).

Alternative food-security indicators: Revisiting the frequency and severity of "coping strategies." Food Policy, 24(4), 411-429. http://dx.doi.org/10.1016/S0306-9192(99)00051-2

Maxwell, S. (2001). The evolution of thinking about food security. In S. Devereux \& S. Maxwell (Eds.), Food security in sub-Sabaran Africa (pp. 13-31). London: Intermediate Technology Development Group (ITDG).

Mccay, B. J. (1981). Optimal foragers or political actors? Ecological analyses of a New Jersey fishery. American Ethnologist, 8(2), 356-382. http://dx.doi.org/10.1525/ae.1981.8.2.02a00080

McClanahan, T. R., \& Cinner, J. (2011). Adapting to a changing environment: Confronting the consequences of climate change. New York: Oxford University Press.
McLaughlin, J. B., Middaugh, J. P., Utermohle, C. J., Asay, E. D., Fenaughty, A. M., \& EberhardtPhillips, J. E. (2004). Changing patterns of risk factors and mortality for coronary heart disease among Alaska Natives. Journal of the American Medical Association, 291, 2545-2546.

Nabhan, G. P. (1990). Gathering the desert. Tuscon, Arizona: University of Arizona Press.

National Marine Fisheries Service [NMFS]. (2010). Fisheries of the United States. Silver Springs, Maryland: NMFS, Office of Science and Technology.

Retrieved from http://www.st.nmfs.noaa.gov/st1/fus/fus10/

National Oceanic and Atmospheric Administration [NOAA]. (2013). National coastal population report: Population trends from 1970 to 2020. Washington, D.C.: NOAA, U.S. Department of Commerce. Retrieved from http://stateofthecoast.noaa.gov/features/coastalpopulation-report.pdf.

Northern Economics. (2011). The seafood industry in Alaska's economy. Juneau, Alaska: Marine Conservation Alliance. Retrieved from http://www.marineconservationalliance.org/wpcontent/uploads/2011/02/SIAE Feb2011a.pdf

Paolisso, M. (2007). Taste the traditions: Crabs, crab cakes, and the Chesapeake Bay blue crab fishery. American Anthropologist, 109(4), 654-665. http://dx.doi.org/10.1525/aa.2007.109.4.654

Paragi, T., Gerlach, S. C., \& Meadow, A. (2010). Security of red meat supply in Alaska. Agroborealis, 41(1), 3637.

Parfitt, J., Barthel, M., \& Macnaughton, S. (2010). Food waste within food supply chains: Quantification and potential for change to 2050. Philosophical Transactions of the Royal Society B: Biological Sciences, 365(1554), 3065-3081. http://dx.doi.org/10.1098/rstb.2010.0126

Pauly, D., Watson, R., \& Alder, J. (2005). Global trends in world fisheries: Impacts on marine ecosystems and food security. Philosophical Transactions of the Royal Society B: Biological Sciences, 360(1453), 5-12. http://dx.doi.org/10.1098/rstb.2004.1574

R Development Core Team. (2011). R: A language and environment for statistical computing. Vienna, Austria: R Foundation for Statistical Computing. 
Richmond, L. (2013). Incorporating indigenous rights and environmental justice into fishery management: Comparing policy challenges and potentials from Alaska and Hawai'i. Environmental Management. Advance online publication. http://dx.doi.org/10.1007/s00267-013-0021-0

Rosset, P. (2008). Food sovereignty and the contemporary food crisis. Development, 51, 460-463. http://dx.doi.org/10.1057/dev.2008.48

Salatin, J. (2007). Everything I want to do is illegal: War stories from the local food front. White River Junction, Vermont: Chelsea Green.

Shiva, Vandana. (2000). Stolen harvest: The hijacking of the global food supply. Cambridge, Massachusetts: South End Press.

Sundkvist, A., Milestad, R., \& Jansson, A. (2005). On the importance of tightening feedback loops for sustainable development of food systems. Food Policy, 30, 224-239. http://dx.doi.org/10.1016/j.foodpol.2005.02.003

Tregear, A. (2011). Progressing knowledge in alternative and local food networks: Critical reflections and a research agenda. Journal of Rural Studies, 27(4), 419430. http://dx.doi.org/10.1016/j.jrurstud.2011.06.003

Trivette, S. (2012). Close to home: The drive for local food. Journal of Agriculture, Food Systems, and Community Development, 3(1), 1-20. http://dx.doi.org/10.5304/jafscd.2012.031.008
United Nations Environmental Programme. (2010). UN atlas of the oceans: Human settlements on the coast. Retrieved from http://www.oceansatlas.org/ servlet $/$ CDSServlet?status $=$ ND0xODc3JiY9ZW $4 \mathrm{~m}$ MzM9KiYzNz1rb3M

U.S. Department of Agriculture [USDA]. (2011a). Welcome to the USD A National Nutrient Database for Standard Reference. Retrieved from http://ndb.nal.usda.gov/

USDA. (2011b). Household Food Security in the United States, 2010. Washington D.C.: United States Department of Agriculture, Economic Research Service. .

USDA. (2013). Supplemental Nutrition Assistance Program: Average Participation (Persons) [Table]. Retrieved from http://www.fns.usda.gov/pd/15SNAPpartPP.htm

World Food Summit. (1996). Rome declaration on world food security and World Food Summit plan of action. Retrieved from the FAO website: http://www.fao.org/ docrep/003/w3613e/w3613e00.htm

Wolfe, R. J., \& Bosworth, R. G. (1990). Subsistence in Alaska: A summary. Fairbanks, Alaska: Alaska Department of Fish and Game, Division of Subsistence.

Wolf, E. C., \& Zuckerman, S. (2003). Salmon Nation: People, fish, and our common home. Portland, Oregon: Ecotrust. 